\title{
Placemaking In Yogyakarta Riverside Settlements, Indonesia: Problems and Prospects
}

\author{
Hastuti Saptorini $i^{1, *}$ \\ ${ }^{1}$ Architecture Department, Faculty of Civil Engineering And Planning, Universitas Islam Indonesia \\ Yogyakarta. Jalan Kaliurang Km 14,4 Yogyakarta, Indonesia
}

\begin{abstract}
Placemaking phenomena in the riverside settlement of Yogyakarta, Indonesia has been created on the independence land. This paper discuss the process of their activities: what, where and how do the activities taking place, by whom, when did they do. These are potentially have some problems, so that it needs the strategy to anticipate. By using the research result funded by Directorate of Higher Education Republic of Indonesia, and updated by self research funded, the activities were categorized and discriptively analysed. Author have found the placemaking criteria achievement in terms of domestic, and recreational activities. Their problems are in terms of illegality, unsafety, and unhealthy conditions. The prospects are in terms of social, economic, and tourism creations which promote strong sense of community, encourage social interaction, income generation, promote sustainability, and attract a strong labour force. On the other hand, it should be developed and managed by regulation, and advocacy to minimize risks.
\end{abstract}

Keywords: placemaking, riverside settlement, social interaction, problems, prospects.

\section{Introduction}

In some developing countries, including Indonesia, there are significantly phenomenal happened in terms of land legal context. The numerous area of independent land has spread out in some places of many big cities, especially in the riverbank. This condition supports many space area seems would be lose because they have no meaningful.

Yogyakarta is one of the many big cities in Indonesia where flowed many rivers. They divided the city geography including the city center. These area would be popular setting of her hinterland commuters who are looking for the occupancies. They are the low income groups in particular. By that moment, they have to earning money (searching job) for support their family lives, whilst making place for living.

\footnotetext{
${ }^{1}$ Corresponding author: hastuti.saptorini@uii.ac.id
} 
They spontaneously built the dwelling in the riverbank co-evolve. They so called as the informal settlement. As Lombard [1] pointed out that the key characteristics usually associated with informal settlements are irregular land tenure, self-build housing, low level of infrastructure and residents with low incomes. Yogyakarta's riverside settlements have similar experiences. The house size were varied depend on their financial capacity and ability, so the room layout scheme are varied as well, including the open spaces as the land remained are distributed in many places. These are enabling residents to using area for numerous activities in terms of fulfillment of their limited housing size. The research found that there are domestic, social, and cultural activities implemented in the river bank, and in the river as well.

These seem to be the placemaking phenomenon. Placemaking is the process by which a space in a location is made meaningful to an individual or a group of people [2]. As Korosec Serfaty in Dayaratne [3] pointed out that "space" could becomes "place" in a process of appropriation. It is usually designed or articulated and in the process of use places are made. This terminology indicates that an understanding of "place" requires a study of what the way in which form, people, and meanings co-evolve [p.43].

Syafarini et al [4] highlighted that placemaking is a philosophy, concept, and approach that gives maximum synergy between the quality of space and human quality in a balanced way in the design and evaluation of space that is considered a failure in the implementation of public space. The working principle is a user-based approach that is able to help city residents transform their public spaces into a vibrant and fun place to visit in their spare time.

In terms of the Yogyakarta's role, it's placemaking phenomena seem to be considered in terms of the images. The role of tourism, culture, and education city, Yogyakarta has recognized of these phenomena. For some people, the placemaking phenomenon in riverside setlement is seen as a problem for several reasons. The impression of slums, unhealthy, and unsafety are the view expressed for those phenomena, so that residents of the settlements are threatened to be evicted.

Fortunately, academics and city authorities took the initiative to take advantage of the phenomenon. The involvement of the inhabitants in building activities of the river and it's bank are directed to a positive product. That is built to the tourist kampung/village. From here, there is a placemaking experience that connotes the negative can be directed to the real placemaking that build positive activities and support Yogyakarta as a tourist city.

This paper aims to examine the experience of riverside settlements that build placemaking with a number of problems, but ultimately thanks to the help of Local Government and advocacy key person who concern with the river area, and becomes the real placemaking as the prospects. The study involves the issue of what activities are developed, how activities are conducted, and who the stakeholders are involved in the phenomenon.

\section{Method}

\subsection{Data Gathering}

The data reviewed in this paper is obtained from the results of previous Author's researches, which were updated and developed through independent research. Research location conducted in some points places of 4 riverside settlement in Yogyakarta: Code, Winongo, Gajahwong, and Tepus. Updating data is collected in the same way through field observation in 2018 and / or the relevant secondary data. 


\subsection{Analysis}

The collected data is analyzed by grouping activities based on phenomenal characters performed by residential groups of riverside settlements. The identification of problems and benefits is analyzed by means of descriptive analysis based on a number of placemaking referenced and relevant theories. Findings of placemaking benefits are reviewed based on theories that reinforce placemaking phenomena in order to find development strategies and their sustainability. Diagrammatically, the method can be seen in Figure 1.

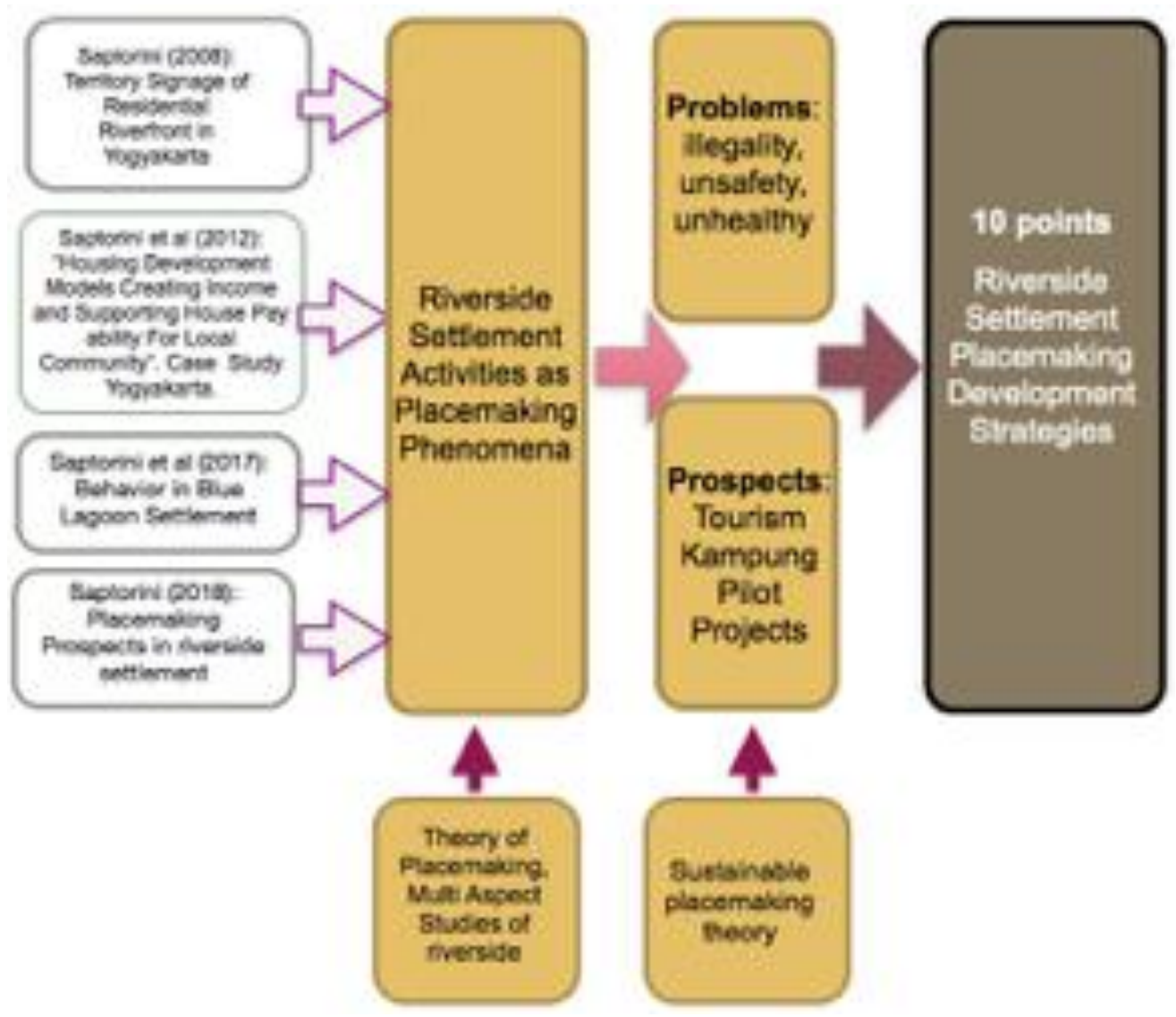

Fig 1. Method

\section{Theoretical Review}

\subsection{Placemaking Principles}

Placemaking is a valuable process of creating public places, which involves people either individually or collectively, interacting with the physical environment through activities. Gehl [5] highlighted this interaction process was indicated the numerous variables: community activities, physical boundaries, social structures, and physical structures. In 
order for neighbor contacts and various forms of communal activities to develop beyond a superficial level, a meaningful common denominator must exist (p.55). Those are common background, common interest, or common problems.

The Richard H Driehaus Foundation [6] highlighted that placemaking is the public space where can be used the people to discover needs and aspirations. They feel strong stake in their communities and commitment to making things better. There are four key qualities of a successful place in these aspects: sociability, access \& linkages, comfort and image, uses \& activities.

The key qualities in sociability aspects, there are many points can be indicated, both intangible and measurable. Some of the intangible indicators are pride, friendly, interactive, welcoming, and so on. The measurable indicators are e.q. social networks, evening use, and street life.

Wollongong City Council has also pointed out that there are 2 items of placemaking aims. Those are:

1. placemaking turn public spaces into places that engage people, and encourage people to stop and become involved.

2. create spaces which offer a rich experience and a sense of belonging, places which have meaning and evoke pleasure, contemplation or reflection, and most importantly, encourage people to show appreciation of the cultural and environmental diversity.

\subsection{Placemaking Approach}

The placemaking approach is to work in creative ways with communities to stimulate new skills and local infrastructure and create enduring and physical reminders of community cooperation. Cultural projects are a direct way to engage with communities and produce outcomes that are unique, visible and permanent reminders of the collaborative process that reflects their own stories.

These were coincidentally meant that placemaking has a strong sense of community and a context for healthy lifestyles and a high quality of life. Some urban designers also emphasize on sustainable communities, encourage social interaction, pedestrian area, cycling transportation, civic pride, and beautiful city. These indicators must be focus on the processes which contribute to their making. If the processes are not healthy, places are unlikely to become meaningful and healthy places [3: p44]. In addition, Dyanita [7] emphasized of Project for Public Spaces (PPS), an internationally recognized organization for information and resources about placemaking, there are four basic characters that make a good place: promotes sociability, offers lots of things to do, comfortable and attractive, and accessible. Placemaking practices and experiences are specific, according to the setting and people situation. In residential riverfront of Yogyakarta, Indonesia, for instance, the way in which places are made in spontaneous settlements and planned settlements differs from most settings and occupants' socio-economic background $[8,9,10]$. Spaces of riverbank in the former can be recognized as being meaningful for accommodating many activities, both domestic, socio-cultural, and economic manners. On the other hands of the latter, spaces of riverbank should not be recognized of those activities, but they are mostly as a barrier, railing, or other upright structure, typically of wood or wire, enclosing an area of ground to mark a boundary, control access, or prevent escape. 


\subsection{Sustainable Placemaking}

The City of Pickering pointed out that there are 10 points of principles city's approach to sustainable placemaking [11]. Those are:

1. draw on the expertise of the community.

2. encourage collaboration at all levels.

3. go beyond design codes; pay attention to function, appearance, and experience.

4. aim for zero impact as the ideal, in carbon and other footprints: minimizing environmental hazards.

5. design and plan for people: place making should be increase social interaction.

6. strive to make Pickering a distinctive community. Placemaking is about create the memorable spaces that people associate with a specific location.

7. adapt to change.

8. learn by doing

9. keep moving in the right direction; the journey will never be finished.

10. strive always to achieve the greater public good. Great places are built by the community and for the community.

\section{Data and Discussion}

\subsection{Residents Background and the House Condition}

The majority of residents are commuters. They come from Yogyakarta's hinterland. The arrival background are the nearer to the occupancy places. Their modus education background is elementary school graduation $(52,8 \%)$. There are just $2,4 \%$ who have university graduation. They have number left spread to junior and senior high school graduations.

These background has properly influenced to the residents' occupancies. The majority of them have informal sectors. Service sectors $(31,3 \%)$ are dominantly, compared to the labour $(27,9 \%)$, trader $(20,4 \%)$, dustmen, and the street musicion $(15 \%)$. The kind of servicing sectors, they have job as the drivers both motor cycle and nor. In the labour sectors, they work as the servants for helping domestic activity of some business wives. These kinds are normally done by women generation. The others have job, by men, as the motor repair and or construction building labour.

In terms of the trading sectors, they have worked as the mobile food traders. soups, fruits, many kind drinks, etc are the kind of food commodities in which were mobile bargained to the neighbour housing. Some of them were also sold their merchandises to the city center were the bussiness activity were going on.

The structure of housing scheme has become linier widespread layout in where the rivers open up. Although, the linier layout is not always implicated the housing face to the river. Some of the housing lines to turn one's back to the rivers, and to face to another. There is no hierarchy in terms of the housing structure and the street. The dwelling unit was independently laid, depend on the land readiness. The houses are normally dense one to the others, so the open space where laid in front of the houses has the role binding.

The housing unit size show that 52,3\% total sample are upper standard housing unit in Indonesia $(36 \mathrm{~m} 2)$. These indicate that there are $47,7 \%$ of the unit dwellings have still limited the housing size. According to their occupancy rate, 4,6 persons per unit house [9], 
these implicate that there are $47.7 \%$ households have still lived in limited dwelling size. These may encourage the occupants to expanding activities outside of their houses.

The construction quality of open space surfaces were varied. There are ground constructions, paving, and concrete one, depending on the creativity and capability of community lived surroundings area. The more creative and capable people the better of construction quality of open space surfaces. By "gotong royong" (mutual help) concept, the open space surfaces were developed by financial sharing of community. The number of contributions are relatives depend on the household number who support and get benefit of the open space.

The open space size are also varied depend on the existing site and the community creating space. The more flat and the clean land surface, the more little size the open space. These caused the people trend to construct the houses by selecting the strategic and moderate land.

\subsection{Cultural, Socio, and Economic Phenomena}

The figure of residents' culture have significantly indicated of the meeting phenomenon. They seem to be frequently making community interaction on behalf many aims and levels, either routinely or insidentally. The parents do the routine meeting, when they need to applied "silaturahiim" activity for strengthening the community bond. This is usually done in the form of "arisan" (collecting and rotating money by mother), "RT" meetings by fathers, etc. The insidentally meeting have been done when the residents need to building agreement of some insidental cases.

Some teenagers and children also have meetings culture in terms of building friendship context. They have made a playing together and or doing something together: socially and economically. Social activities were implied such as swimming, sport activities, etc. The children sometimes play and swim together in the river and its bank. They do spontaneously by leisure motivation and psychomotor aspects in terms of naturally psychological children growth. These phenomena have also affected to building togetherness and children community bond.

Economic actitivities were implied sech as fishing together, farming, fruiting, forresting, etc (Fig. 4). The teenagers routinely do these activities, even these sometimes used to be working for helping their parents to earn money.

\subsection{Residential Activities.}

The Yogyakarta residential riverfront experience has seems indicated to the place making phenomena. As Dovey highlighted that place making is the process by which a space in a location is made meaningful to an individual or a group of people [2], the residents activities have expressed some meanings in terms of their lives and settlement desired.

When the women using river water, this means that the residents were making the space of river water to be meaningful for the people who use it. They feel to get the benefit of the water, because the river's useful, either the water or the bank. That activity style has been valued to encourage social interaction and to support aging of the community. By doing that activity could be meant the community are reaching the end of useful life.

As Korosec Serfaty in Dayaratne [3] points out that "space" could becomes "place" in a process of appropriation. In terms of the washing in the river, it is space where are designed or articulated by the residents to be using places. This indicates that by interaction way, women evolve the river to be living atmosphere and leading to environmentally friendly 
place (Fig.2.). Although some of disadvantages should be considered in terms of the slum visual image, their healthy, and safety. These disadvantages may be caused by many problems both of the land tenure, and economic background.

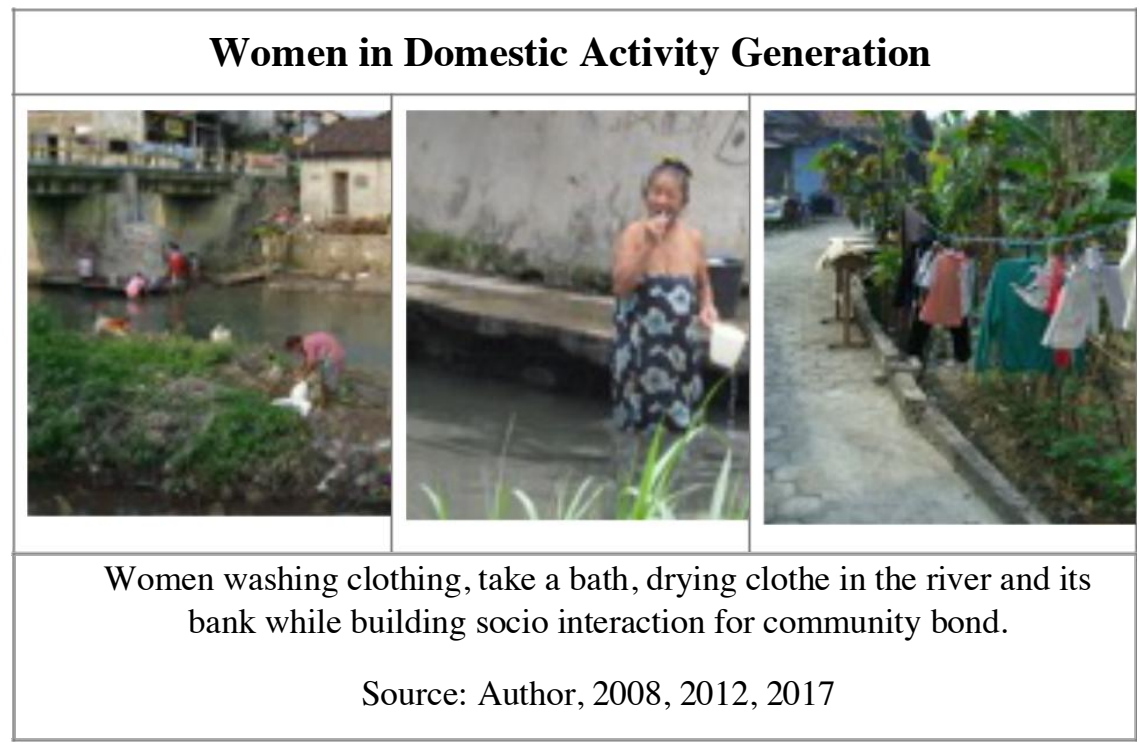

Fig. 2. Activity Generation in The Rivers and Its Banks

\section{Children and Teenegers in Leisure Activity Generation}
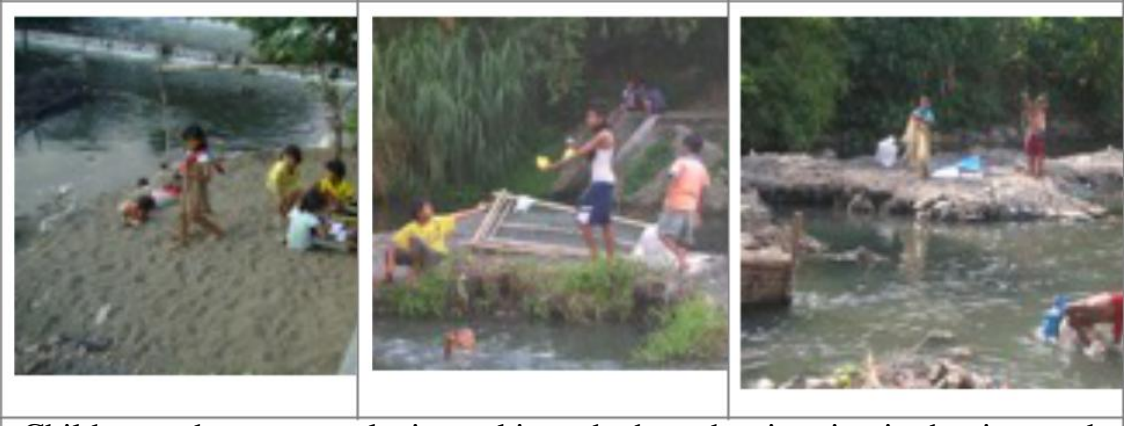

Children and teenegers playing, taking a bath, and swimming in the river and its bank for getting leisure activity, togetherness, and supporting naturally

psychological children growth.

Source: Author, 2008, 2012, 2017

Fig.3. Children in Togetherness Activity

In terms of men activity, residents have generated some economic activities. As the household capacity, men (father community) have played a role in the form of doing economical activities. Some of residents use the independent open space, either water river, 
riverbank, or street for making fish ponds, stone collector, cycle repair area, trading food, storing trading stuff, etc. The independent open spaces were usually selected in where near their houses. These phenomena seem to be promote sustainability and generate a high quality of life by creating activities leading to income generation.

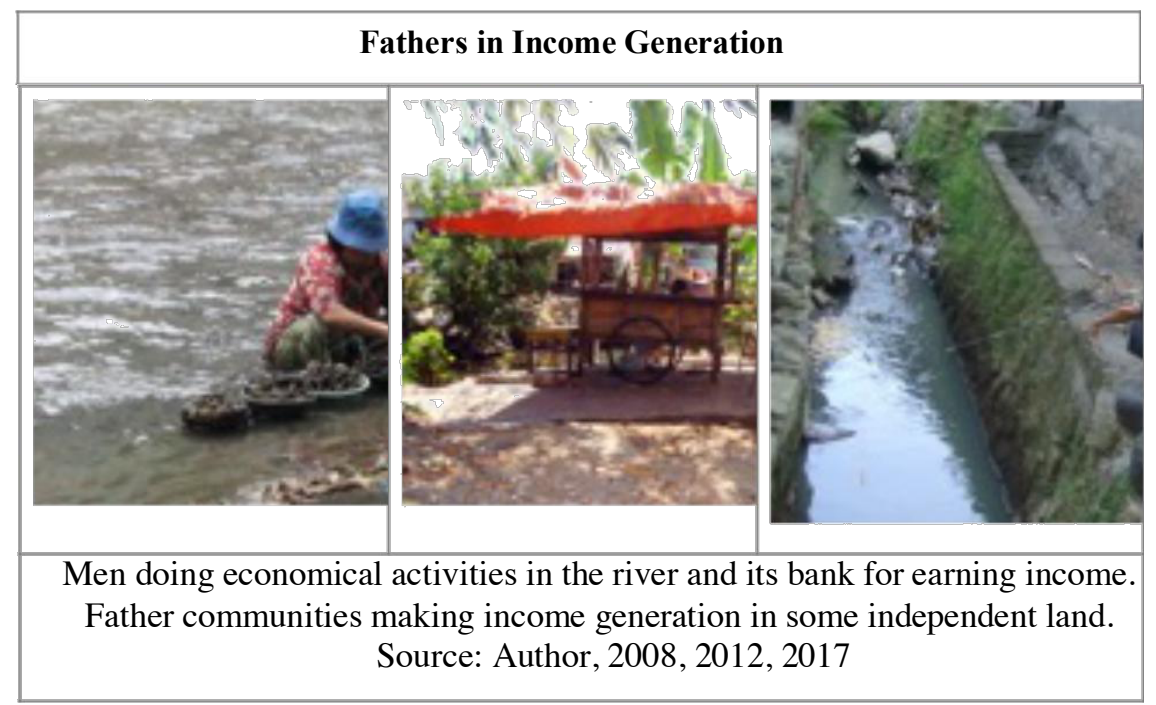

Fig.4. Father Community in Economic Activity

These indications may to be a power talent of the low income groups who live in the riverfront area. The women creation of using river water for washing some clothes and other stuffs have indicated that they could transform the space into place whilst building community interaction. The similar phenomenon has been indicated the teenagers that have created the content of the river to collecting fishes for sold and or selves consummed. In addition, the children have used the bank river for playing together. This means that the youngest community also have created the space into the funny place.

\subsection{Problem and Prospects for Sustainability}

For the residents, altering 'space' into 'place' seem to be natural 'development' may forced situations. The limitation of their house's conditions, both the type of room, the measurement, and the construction quality, residents have naturally done in any area where accessible and available. These may would keeping some problems caused of nothing residents' concepts of the 'development'. There are three problems opportunity are based on non physical aspects leading to physical aspects. Non physical aspects is illegallity, and physical aspects are unsafety, and unhealthy.

\subsubsection{Illegality problem}

The majority of housing status categorised illegal because they do not conform with formal procedures and standards concerning land and building aspects. Setiawan [12] also had the similar findings [p.3]. Residents's recognition of the land status are from generation 
to generation, that is one of the Sultan Ground's type which manifestated of "wedi kengser" one. This means that they could occupy the land since they would like without the legal certificate land. Although, this has opportunity to eviction when government would like this land for creating some project urban development. Tenure security is the main problem because influences to the residents's spirit in improving the houses.

Setiawan [12] highlighted that land security leads to improvement (p.7). Although, it is not always true that 'legalization' is necessary for improvement. It is assumed that by giving security the land tenure, people feel secure because they will not evicted, hard working and earning more money to develope their houses.

The land legality for riverside settlements is still a complicated issue. Several efforts have been made to assist the issue. Unfortunately, the efforts undertaken are still limited to scientific studies and/or appointment cases in student academic projects. For example, Suparno, a student of the Undip Law Program in Kenotariatan. In his study, the policy of the Mayor of Surakarta underlined that land resources have 6 (six) types of value [13], namely: a. production value, b. location value, c. environmental value, d. social value, and e. political value and $\mathrm{f}$. legal value. This means that the role of the government is not only limited to efforts to improve the mechanisms that can allocate land resources, but also requires an institution to assume the above functions, so that the land can be utilized in a more prosperous, equitable and motivable for the community. A temporary solution that can support residents' security is by rental payment, to maintain of the settlement neighbourhood and the aesthetic visual image.

\subsubsection{Unsafety problem}

The low spirit and capasity to improving, some of housing conditions were looked as the "freckles" of urban image because of the unstandard construction. The limited financial residents' capability affected the awful quality in utilizing the infrastructure of economic activity. They eventually apply the reuse building materials for erecting their houses so those have visualized the 'slum' environment image and the constructions have temporary quality. This sometimes makes worried the urban observer, especially urban designers and the stakeholders of urban management, in terms of the visual comfort and safety. The residents, however, are not feel unconvenient of those condition, even they seem happily doing activities in the circumtances. These problems may a little bit opposed with the place making principle that the safety, fun, charming, and welcoming, tend to come up repeatedly. As long as those circumstances have many problems condition, the outsiders have no access of not fulfilling the requirement of the intangible quality of place making.

The experience of some observers noted that during the peak rainy season, several nodes of the settlement were flooded to a height of $50 \mathrm{~cm}$. Even, when Merapi erupted in 2010, almost all riverside settlements were submerged in mud. This condition certainly threatens the occupants' activity, especially were done on the riverbanks.

\subsubsection{Unhealthy Problem}

In terms of healthy aspects, the residents sometimes spread out some deseases: stomach ache, iching skin, head ache, etc. The environment condition seem to be the reason of the deseases. The river water quality which used swimming, taking bath, washing, may be the reasonable factors. Yet, the place surface where children playing is soil, so it is possible they sometimes spread out stomach ache caused they unused shoes or slippers. 
The culture of dumping waste into rivers leads to chemical and biological levels that threaten water quality and the riverside communities that utilize it. Wastes of faeces, both humans and animals, disposal industrial waste which are dumped into the river result in the content of nitrate and phenol exceeding permissible quality standards [14]. This is resulted to riverside residents threatened health when active in the river.

As Dayaratne highlighted that if the processes are not healthy, places are unlikely to become meaningful and healthy places. In terms of the women doing domestic activity in the river, father generating economic activities in the independent open space, children and teenagers doing socio activities seem to do by synchronizing the characteristic of residential setting, either physically or non-physically. These mean that communities have done some activities in the surrounding of their settlement by considering the consequences.

The river behavior sometimes indicates the dangerous phenomenon, especially in raining season. The significant water stream sometimes make a threat the residents caused the flood potential. Therefore, the some economic activities by fathers, fishpond e.g., would be got a rest till the safety condition. This situation, thus, tends to make the income generation would not be sustainable.

As Dyanita [8] highlighted of four basic characters that make a good place: promotes sociability, offers lots of things to do, comfortable and attractive, and accessible, the experience of Yogyakarta riverfronts community have already expressed those variables. Social interaction among women in washing activity, playing together among children, and fishing activity among teenegers have already expressed the sociability. These have also supported the Gehl's concept of community activities.

The using some independent spaces in riverbanks for those activities have also expressed that these areas have offered of things to do, both in the river and in the edges. When the rivers situation are safety, some children sometimes take a bath while swimming as the sport and playing activities. Women and men also plant some vegetations in their available land of surrounding settlements. They plant some kind of fruits (mango, papaya, banana, rambutan, etc), vegetables (chili, spinach, tomato, etc), and herbals (guava, orange, etc) for fulfillment their daily lives.

The comfortable and accessible characters, the experience of Yogyakarta riverfronts community give the significant value. Their settlement surroundings area have already built so these encouraged people to access them. The settlement infrastructures have already gradually built by community participatory and some NGO's involvement. Road steps and streets construction, electrical networking, and the some MCK's (Wash and Bath Communal) were built by those stakeholders and are maintained by community so that their environments safety and comfort to access.

These experiences seem to be considered in terms of sustaining community participation in community development for building environment. These should be synchronized between stakeholders. The creative residents' activities are the talents to create the real living places. Therefore, those potentials phenomena should be assigned and financed for resulting the more attractive and aesthetic images of the environment.

\subsubsection{Prospects}

Widodo et al [15] underlines that community empowerment is one of the strategic riverfront development models. This community development model involves their participation to build a sense of belonging so that all riverfront resources are open access and common property in their environment. This concept is used by the Government of Yogyakarta in responding to the phenomenon of the settlement of the riverbank. Through 
the program "Kampung Wisata" which involves the key person in to mobilize residents in the neighborhood, built environmental recovery process. A number of nodes of riverside settlement in Yogyakarta built a number of Local Government programs that essentially utilize the phenomenon of placemaking, by minimizing the negative risks. The Clean River Program, called "Prokasih", "Kampung Wisata Code", "Child Friendly Village", etc., is many Local Government's programs built to minimize the negative risks of placemaking phenomena (Fig.5).

A number of village improvement programs are pilots of local government projects to trigger and set a concrete example of building riverbanks in general and riverside settlement areas in particular. The hope is, for the Government, the development can run gradually and be imitated by other community groups, so that the construction of riverside settlements awakens beautifully, intact, and widespread. For riverside settlement communities, they can move in their environment with a sense of security, health, and comfort. Thus, the phenomenon of placemaking that has been built socially, economically, and culturally remains ecologically valuable and sustainable.

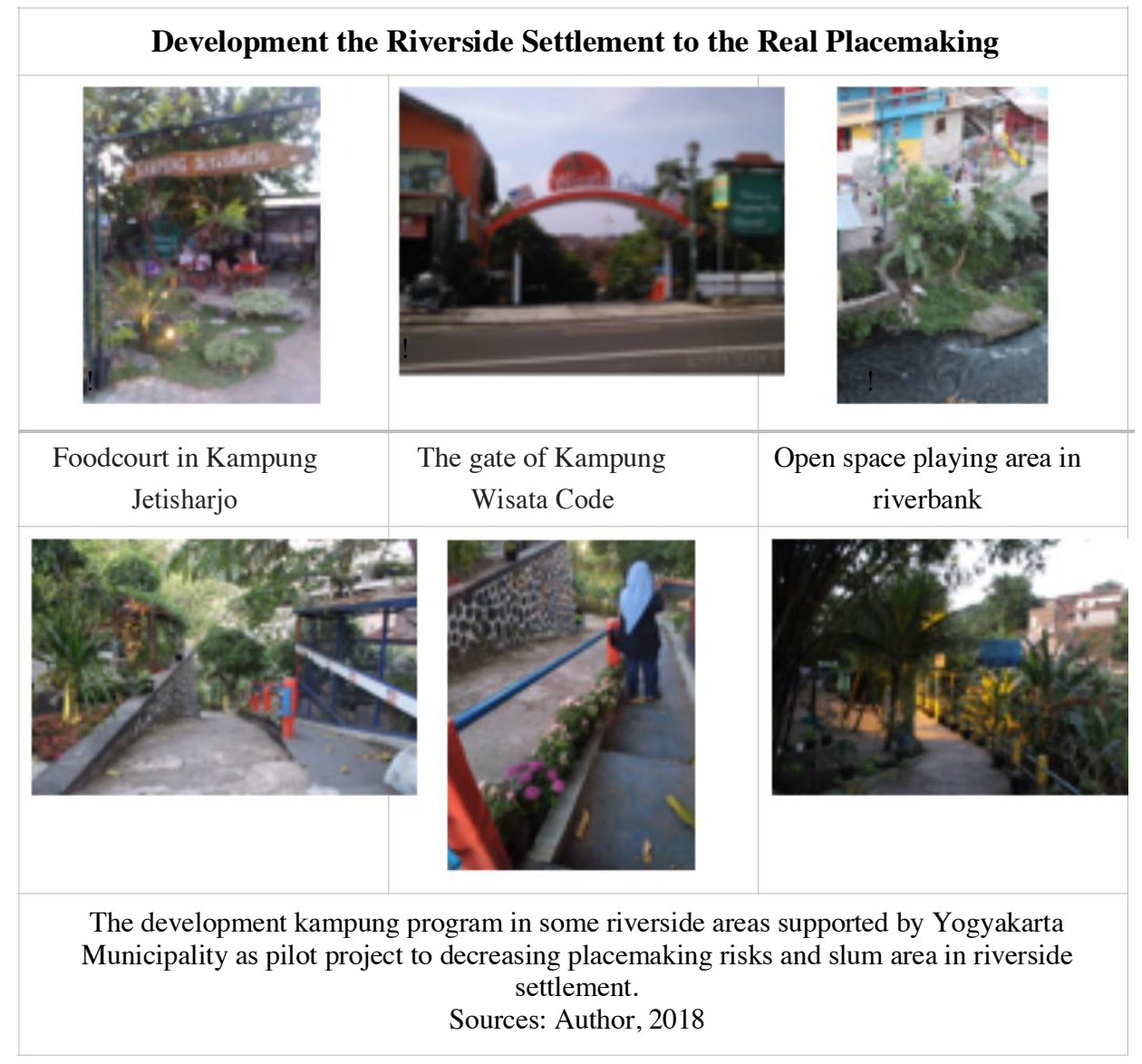

Fig. 5. Placemaking prospects 


\section{Strategy of Riverside Settlement Placemaking Development: Conclusion \& Recommendation}

Based on the riverside settlement placemaking phenomenon, problematic findings and their prospects are valuable experiences may be considered for running sustainable urban settlement development. Referring to the city of Pickering principle, Yogyakarta's experience in addressing the phenomenon of placemaking of riverside settlements can be noted as a sustainable development strategy. The following ten points are strategic parameters that can be taken into consideration in the development of sustainable riverside settlements.

Some non-government organizations (the NGO 's) are also significantly needed in involving resident advocacy. They may be got a role as the technical assistants in terms of the realistic urban design. The low education background of the residents may needed some thought supports in achieving considerations of the safety and aesthetic visual image, so that the existing potential place making criteria could be remained as the sustainable local genius and thus supporting Yogyakarta development.

1. Enforcing the community's expertises. The key person involved in Kampung Wisata Code, Prokasih, and so forth is a local community of Yogyakarta with expertise, both sociology and managerial, who succeeded in mobilizing the community's potential to minimize the risk of previous placemaking phenomena.

2. Building stakeholders collaboration. The collaboration between the local Government of Yogyakarta, the key person involved, and the local community is the key to the success of building a beautiful, safe, and comfortable impression on the environment.

3. Focusing to function, appearance, and experience. The principle of the benefits of the development of Prokasih, Kampung Wisata Code and so forth is felt by the residents both from the economic, social, cultural, and even psychological side, as when they build the previous place making. The beauty and cleanliness of the riverside environment after it is built, the interaction with the tourist guests is an experience that motivates the inhabitants in improving the quality of healthy and sustainable living.

4. Minimizing environmental hazards. The often receive tourist guests who visit the residential location, residents automatically maintain the cleanliness and beauty of the environment. Indirectly, residents have ashame culture when they live in a dirty and dangerous environment.

5. Increasing public space for social interaction. The number of culinary spaces for tourism built in the Tourist Village of Code is an open space and semi open spaces that have been used for social interaction around the riverside settlement.

6. Creating memorable spaces. Completeness of the landscape elements built in the Kampung Wisata Code has menanmkan separate memories when doing activities on the banks of the river. Colorful flowers, adequate and romantic lighting, are examples of landscape elements that delight travelers to build memories in their minds.

7. Adapting to change. Riverfront settlements located in urban contexts, it is possible to change the conditions for possible investor influence. Similarly, the location of the river that often become water subscriptions overflow, is an opportunity for changes in the configuration environment Kampung Wisata Code. 
8. Learning by doing. A number of community-driven development programs implemented by local government are community lessons that are implemented while carrying out development.

9. Making continuum attraction. Fishing activities while buying food in the tourist kampung made by tourists and the surrounding community is a placemaking attraction that rolls every time.

10. Envolving community in development. The mutual (gotong royong) model when cleaning the river in Prokasih program, and the landscape maintenance system that is charged to the nearest settlers are the development scheme involving the local community.

\section{Aknowledgment}

This paper was dissemination of the three research results. The two research funded by The General Directorate of Higher Education, National Education Department of Indonesia in 2008 and 2012. Presently, the name is Ristek Dikti. The first one is fundamental reseach by title "Territory Signage of Residential Riverfront in Yogyakarta". The second one is competitive grant research by title "Housing Develoment Models Creating Income and Supporting House Payability For Local Community". Case Yogyakarta. The author gratefully thanks to the financial sponsor, so this hopefully useful for the academic quality development.

\section{Reference}

1. M. Lombart, Constructing ordinary places: Place-making in urban informal settlements in Mexico, Progress in Planning 94, Elsevier, UK (2014).

2. K. Dovey, An Ecology of Placemaking, in Conference of Place and Place Making, Melbourne, (1985).

3. R. Dayaratne, Supporting People's Place Making. The Case of Support Housing

4. in Sri Langka, Forum Journal of Newcastle upon Tyne University, Annual Publication of The Cardo Research Group, Newcastle upon Tyne, UK, (1992).

5. R. Syafrini et al, "Placemaking Di Ruang Publik Tepi Laut Kota Manado", Media Matrasain Vol.10 No 1 Mei (2013).

6. J.Gehl, Life Between Buidings, the Danish Architectural Press, Copenhagen (2001).

7. The Richard H. Driehaus Foundation, Project for Public Spaces, Metropolitan Planning Council, New York (2008).

8. D. Dyanita, Building Creative Community Online: Placemaking on the Web, International Conference Arteo Polis 2 ISBN: 978-979-18399-0-7, ITB Bandung (2008).

9. H. Saptorini , 2006, Teritorialitas Permukiman Tepi Sungai Code, Jurnal Dimensi Arsitektur Universitas Petra, Volume 34 No.1, Juli, Hal. 31 - 39, Surabaya (2006).

10. H. Saptorini, et al, Housing Development Models Creating Income and Supporting House Payability For Local Community. Case Study Yogyakarta, Unpublished, (2012). 
11. H. Saptorini, et al, Mapping Of Affordaance And Activity As The Biophilic Design Principle Of Blue Lagoon Tourism Area Yogyakarta, SHS Web Of Conference Volume 41, ISBN: 978-1-5108-5577-9, p.173-184, (2018).

12. City of Pickering, The Corporation of the City of Pickering, Canada (2014).

13. Setiawan, Bakti, The Future of Kampung in Indonesia: Costs and benefits of Illegality, International Paper Presentation in Public Works of Indonesia, Yogyakarta, (2009).

14. Suparno, Pelaksanaan Permohonan Hak Atas Tanah Di Sekitar Bantaran Sungai Di Kota Surakarta, Thesis yang telah dipertahankan di Depan Tim Penguji di Program Kenotariatan Universitas Diponegoro Semarang pada 15 Desember 2005 dan dinyatakan telah memenuhi syarat untuk diterima, unpublished, (2005).

15. E. Yogafanny, Pengaruh Aktifitas Warga di Sempadan Sungai terhadap Kualitas Air Sungai Winongo, Jurnal Sains dan Teknologi Lingkungan Volume 7, Nomor 1, Januari 2015 Hal. 41-50, (2015).

16. Widodo B. et al, Pengelolaan Kawasan Sungai Code Berbasis Masyarakat, Jurnal Sains dan Teknologi Lingkungan Volume 2, Nomor 1, Januari 2010, Halaman 7-20 ISSN: 2085-1227 (2010). 